\title{
THE LINKAGE OF EFFECT CLIMATE CHANGE FOR DETERMINING DESIGN FLOOD OF TENGGANG RIVER
}

\author{
Marelianda AL DIANTY ${ }^{(1 D}$, Rizka ARBANINGRUM ${ }^{1}$, Frederik Josep PUTUHENA ${ }^{1}$
}

DOI: $10.21163 / G T \_2020.151 .17$

\begin{abstract}
:
Extreme Flood events due to climate change have been hit Semarang City several times. The disaster usually occurs because of the development of flood protection generally does not include climate change factors on the design flood. The paper was appointed to characterize rainfall run-off with 10 years of historical data from three rain gauge stations likely Wolo, Brumbung, and Maritim. The analytical showed annual rainfall and maximum daily rainfall tends to increase on average $2.139 \mathrm{~mm}$ per year, the number of rainy days tends to decrease two days per year. The future Intensity Duration Frequency (IDF) is needed to anticipate global temperature increases more than 2 degrees. Whereas the analysis for drainage capacity showed by the intensity return period of rainfall for $2,5,10,25,50,100$ years were 81.656 $\mathrm{mm} /$ hour, $104.262 \mathrm{~mm} /$ hour, $116.00 \mathrm{~mm} /$ hour, $126.511 \mathrm{~mm} /$ hour, $132.773 \mathrm{~mm} /$ hour, $138.030 \mathrm{~mm} /$ hour. With the findings, it is expected to develop a flood control system, simply considering the impact of climate change. Hence, the research is successful to predict the flood in a small catchment, with historical data only. The result contributed to one frame that it should take into account the necessity of flood mitigation, including the climate change impact.
\end{abstract}

Key-words: Flooding, Hydrograph, Intensity, Rainfall, Climate Change

\section{INTRODUCTION}

Nowadays, the occurrence of flooding in Semarang City significantly tends to increase from time to time. It caused by several factors likely land-use change, the impact of climate change and land subsidence. The effect of land-use changes as well as land subsidence have been thoroughly studied and discussed (Fu et al., 2003, De Paola et al., 2014, Califano et al., 2015). While the effects of climate change in terms of hydrological factors have not been much discussed. As well this problem might take into account in the drainage systems and flood control management. According to Suripin \& Hilmi (2015), climate change has brought modification in the rain characterization. It is shown by the duration of the dry season is getting longer where the number of rainy days tends to decrease, while the maximum daily rainfall and intensity tend to increase.

Climate change due to global warming is no longer an issue but has become a reality, the effects and the damages have been we felt together. Climate change occurs because of internal natural processes or external forces, or due to human activities that continuously change the composition of the atmosphere (Shrestha \& Zinck, 2001, Murdiyarso, 2003). Climate change is characterized by changes in climate events. One of the indicators is rainfall. Rainfall as seen as the most important climate change variable because it is prompt to

\footnotetext{
${ }^{1}$ Civil Engineering Program and Center of Urban Studies Pembangunan Jaya University, Jl. Cendrawasih raya, 15413, Bintaro Jaya Tangerang Selatan, Indonesia, marelianda.aldianty@upj.ac.id, rizka.arbaningrum@upj.ac.id,
} 
the activities of human life in various sectors such as agriculture, transportation, trade, health and the environment. In the same way, rain is one of the most unpredictable atmospheric variables, and it is still a big challenge for meteorological researchers (Emanuel, 2005).

In the tropical country, rainfall acknowledges as the most varied physical element of the environment. This region does have a high level of non-linearity, so the atmospheric conditions of this region are more difficult to predict in compared to the other regions with high latitudes. So far, empirically scientists have been found that global warming will increase the rainfall. Since the extreme rainfall in the tropics is more sensitive to the effects of climate change than other regions of the world. But the mechanism of the increasing intensity of rainfall is not yet well understood (O'Gorman, 2015). The impact of high intensity of rainfall is evoked potential extreme flooding on the tropical countries. Hence, the modelling should provide a sufficient rainfall run-off analysis, especially for the equatorial region like Indonesia. As identified Pravalie (2014), the rainfall run off analysis needs data of mean monthly and annual temperatures $\left({ }^{\circ} \mathrm{C}\right)$, and monthly and annual amounts of rainfall $(\mathrm{mm})$ and potential evapotranspiration $(\mathrm{mm})$. Generally, the diversity of rainfall in Indonesia is influenced by its presence on the equator, monsoon activity, the stretch of the Pacific and Indian oceans as well as very diverse forms of topography (Diaz et al, 2006). According to the World Wildlife Fund in the period of 100 years, the average annual temperature in Indonesia was increased to 0.72-3.92 degrees involved the intensity of rainfall was become decreased to 2-3 percent. In the same way, the study also a summary in the southern part of Indonesia, the rainfall has been shifting to one month slower with an increase of the intensity of rainfall up to 10 percent in the rainy season and the reduction of rainfall intensity about 75 percent in the dry season (WWF, 2012). Furthermore, Wayan \& Yatim (2019) was reported similar situation from the neighbouring country of Indonesia that annual mean temperature increased from 0.99 to $3.44^{\circ} \mathrm{C} / 100$ years.

From those issues, this research provides flooding control and development of the drainage system by rainfall run-off analysis. Despite other findings are still conventional, it does not include climate change parameter in determining design flood. Based on this condition, we aim to find the rainfall run off by historical data analysis. More importantly, we develop the analysis of rainfall Intensity Duration Frequency (IDF) which is the amount of rainfall expressed by height and volume of rainfall. The effort requires the IDF modelling to design extensive drainage systems. The analytical solution of this study, it is expected to develop drainage systems and or flood control, especially in a small catchment area.

\section{STUDY AREA}

\subsection{Characteristics of Tenggang River}

Tenggang River is a unique river because it is located in several sub-districts in the city of Semarang from upstream to downstream. The upstream part of the river is located in Pedurungan while the downstream is in Genuk and the rest of the part is in Gayamsari. The catchment area of Tenggang River has around $25.48 \mathrm{Km}^{2}$. Currently, Tenggang River has less functioning with poor drainage channels due to the frequency of flooding in the Catchment Area in Tlogosari. Instead, the river Tenggang is quite large and able to flow through the existing water flow, but there are several things that make this channel runoff or flood. What often happens is silting up and the presence of illegal buildings that hinder the flow of water towards the downstream.

The soil type in the Tenggang river is dominated by the Gray Alluvial about 64.21 percent, Mediteran Dark Brown around 27.02 percent, Regosol 7.82 percent and a small 
portion of Reddish-Brown Latosol about 0.73 percent and next Alluvial 0.22 percent. Soil Alluvial Gray and Alluvial Association are found in the upstream part, while the downstream is dominated by the brown mediteran and a little Grumusol. Alluvial soil type is soil formed from river mud that settles in the lowlands which have fertile soil properties and is suitable for agricultural land. While grumusol soil is soil formed from soft clay material. This soil type is black gray and is fertile. Grumusol soils generally have a clay texture and break easily during the dry season. While, the composition of land use planning around the river consists of Tambak 7.64 percent, 15.96 of urban, settlement 30.42 percent and rice fields around 45.99 percent (Pintubatu et al., 2013).

\subsection{Rainfall Stations}

Tenggang River is a river that stretches from around the area of Tlogosari Raya street, Muktiharjo Raya street, Kaligawe Raya street then until the North Sea of Java. Those areas were often affected by floods and tides. There are three rain gauge stations located close to the Tenggang river likely rain gauge station Wolo, rain gauge station Brumbung and rain gauge station Maritim. Moreover, the study area was divided into 23 sub-basins as follow showed in (Fig. 1).

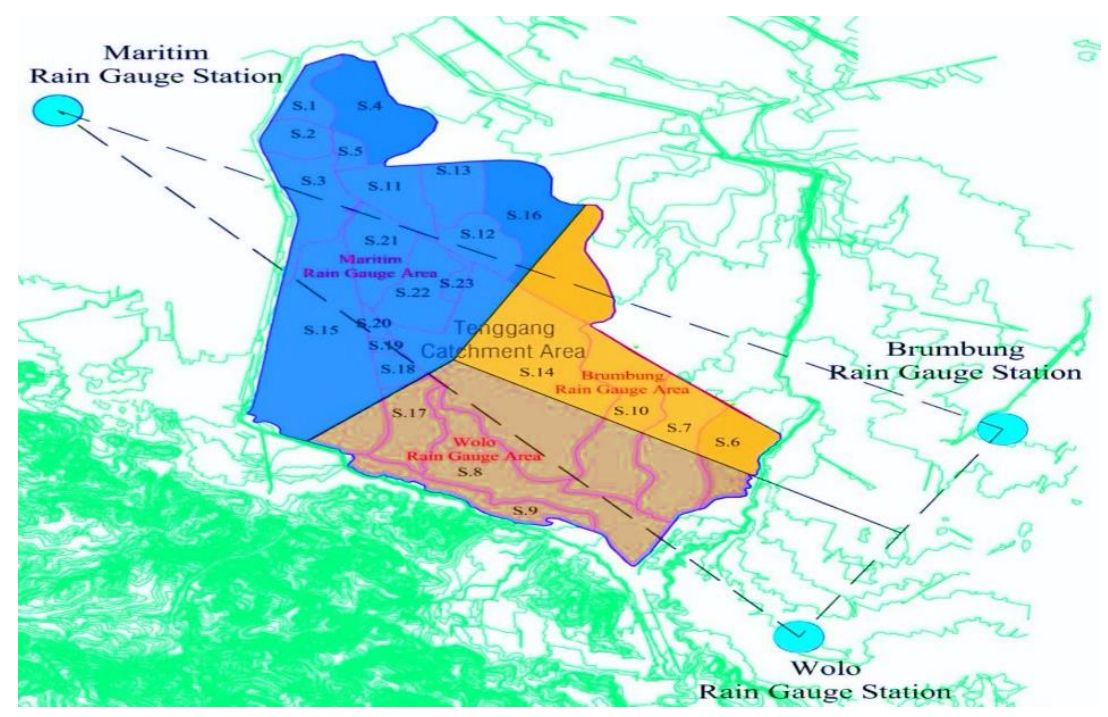

Fig 1. Map of Tenggang River

\section{METHODOLOGY}

\section{1 Rainfall Analysis}

Rainfall analysis is carried out by analysing regional rainfall and performed it on the peak of annual rainfall, number of rainy days and maximum daily rainfall. Where it is useful to characterize the rainfall run off. In determining rainfall elements from recording data, only rainfall is obtained at a certain point (rainfall point) used in the analysis. The techniques used to analyse rainfall trend were the rain gauge data from 2006 - 2015. Furthermore, to get the rainfall characterization the area is calculated using the Thiessen Polygon method, as follow: 


$$
R=\frac{A_{1} R_{1}+A_{2} R_{2}+\cdots A_{n} R_{n}}{A_{1}+A_{2}+\cdots+A_{n}}
$$

\subsection{Hydrological method}

\subsubsection{Intensity Duration Frequency (IDF)}

Rainfall intensity is the height or depth of rainwater per unit time that occurs at a time period where the water is concentrating. The general nature of the rainfall is the shorter of the rainfall occurs, the intensity tends to be higher and the greater of the return period so the intensity of rainfall will be higher. The relationship between intensity, duration of rain and frequency of rain is usually expressed in the curve Intensity - Duration - Frequency (IDF). Short-term rain data is needed to form the IDF curve. This type of rainfall data can be obtained from rain gauge stations. To calculate the intensity of rainfall can be used equation as follows:

$$
I=\frac{R_{24}}{24}\left[\frac{24}{t_{c}}\right]^{2 / 3}
$$

In the process of converting the rainfall into flow, there are several characteristics of rainfall that used including the intensity of rain $(\mathrm{I})$, length of time $(\mathrm{t})$, depth of rainfall $(\mathrm{d})$, frequency (f) and the area of influence by rainfall (A). The rainfall component with its properties can be analysed in the form of point the rainfall and average rainfall which covers the catchment areas. It can be used daily rainfall to calculate intensity in mm per hour. The analysis of the relationship of two important rainfall in the form of intensity and duration can be statistically related to a frequency of occurrence to find calculation planning of flood discharge by rational method with the equation as follow:

$$
Q=C x I x A
$$

\subsubsection{Flood hydrograph model}

Hydrograph is defined by the relationship between surface flow or base flow with time. While, flood hydrographs itself are a graph to illustrate a drainage basin which will responds to the period of rainfall. The method is predominantly useful for observed floods and catchment characteristics (Hall \& Minns, 1999). Flood hydrograph in a catchment area depends on various factors, its related to runoff and the elements that express the physical characteristics rainfall. It is valuable for deriving flood hydrographs that incorporate realistic floods peak and volume of rainfall were distributed realistically in time. As well Virginia et al (2016) have been demonstrated flood hydrograph on the large amounts of unconsolidated material such large wood under different unsteady flood scenarios.

Flood hydrograph in this research is developed by Hydrologic Engineering Centre's Hydrologic Modelling System (HEC-HMS). The software is used in water resources management planning. HEC-HMS is used for hydrological analysis by simulating the rainfall 
and runoff processes of a river basin. Flood hydrographs are obtained by comparing flood hydrographs due to rainfall at various re-times. Additionally, the analysis of the design flood is performed using "HEC-HMS" software. Outputs of this software include rainfall intensity and flood hydrograph. Model hydrograph that we used in this case is using Soil Conservation Service (SCS) model. The model was recognised have accurate results therefore it is broadly applied (Gyori \& Haidu, 2011). Besides, HEC-HMS gives an accuracy answer and a reliable model with reasonable approximations to perform the rainfall-runoff modelling (Haidu et al., 2017). Moreover, to complete this hydrological analysis on flood hydrograph is used by analysing some of its parameters as follows:

$$
\begin{gathered}
T_{c}=\left(\frac{0.87 \times l^{2}}{1000 \times \Upsilon}\right)^{0.385} \\
L=0.6 T_{c}
\end{gathered}
$$

$L:$ lag time (hours), $T c$ : time concentration (hours), $l:$ length $(\mathrm{km}), Y:$ slope

\section{RESULTS AND DISCUSSIONS}

\subsection{The characteristics of rainfall}

The rainfall characteristics have been done by regression analysis to discover the correlation between rainfall parameters and the time. The parameter included annual rainfall, number of rainy days, and maximum daily rainfall. The analyses of the trends in rainfall were identified using the Thiessen polygon method. it carried out on three rain gauge stations that have historical data, in this case, 10 years. The watershed areas were divided into $50 \%$ of Maritime rain gauge stations, $30 \%$ of Wolo rain gauge station and $20 \%$ of Brumbung rain gauge station. The rainfall characteristics are shown in (Fig. 2). The figures illustrated Brumbung rain gauge station has the significance of the linear trend is compared to other rain gauge stations. Subsequently, Maritim rain gauge station revealed to high intensity of rainfall each year. While, Wolo rain gauge station perform contrarily significant for all years. Moreover, it also found in the year 2010 indicated as the peak of rainfall in all rain gauge stations. The analysis revealed that a large number in the same rainfall event has contributed to extreme rainfall. Therefore, it needs an additional rain gauge station at the catchment area. As demonstrated by Yavuz \& Erdoğan (2012), it is necessary to have sufficient rain gauges distributed in the optimal locations.

From the result, it can be seen, the annual rainfall and maximum daily rainfall tend to increase, while the number of rainy days tends to decrease. The annual rainfall from Brumbung station appears to have more consistency. While the average daily rainfall tends to vary in Maritim rain gauge station from month to month. Hence, it needs to have a reliability assessment in those stations (Martin et al., 2015). Peak annual rainfall increased by an average of $12,094 \mathrm{~mm}$ per year, while the maximum daily rainfall increased by an average of 2,139 mm per year, and the number of rainy days decreased by an average of 2 days per year. From the result, the peak of annual rainfall it seems to have similarity with research conducted by Mello et al (2013) in Brazil, the characteristics of rainfall in Tenggang river was present potential high intensity of rainfall. Hence, its essentials to be taken into account for hydrological and water management in this area. 


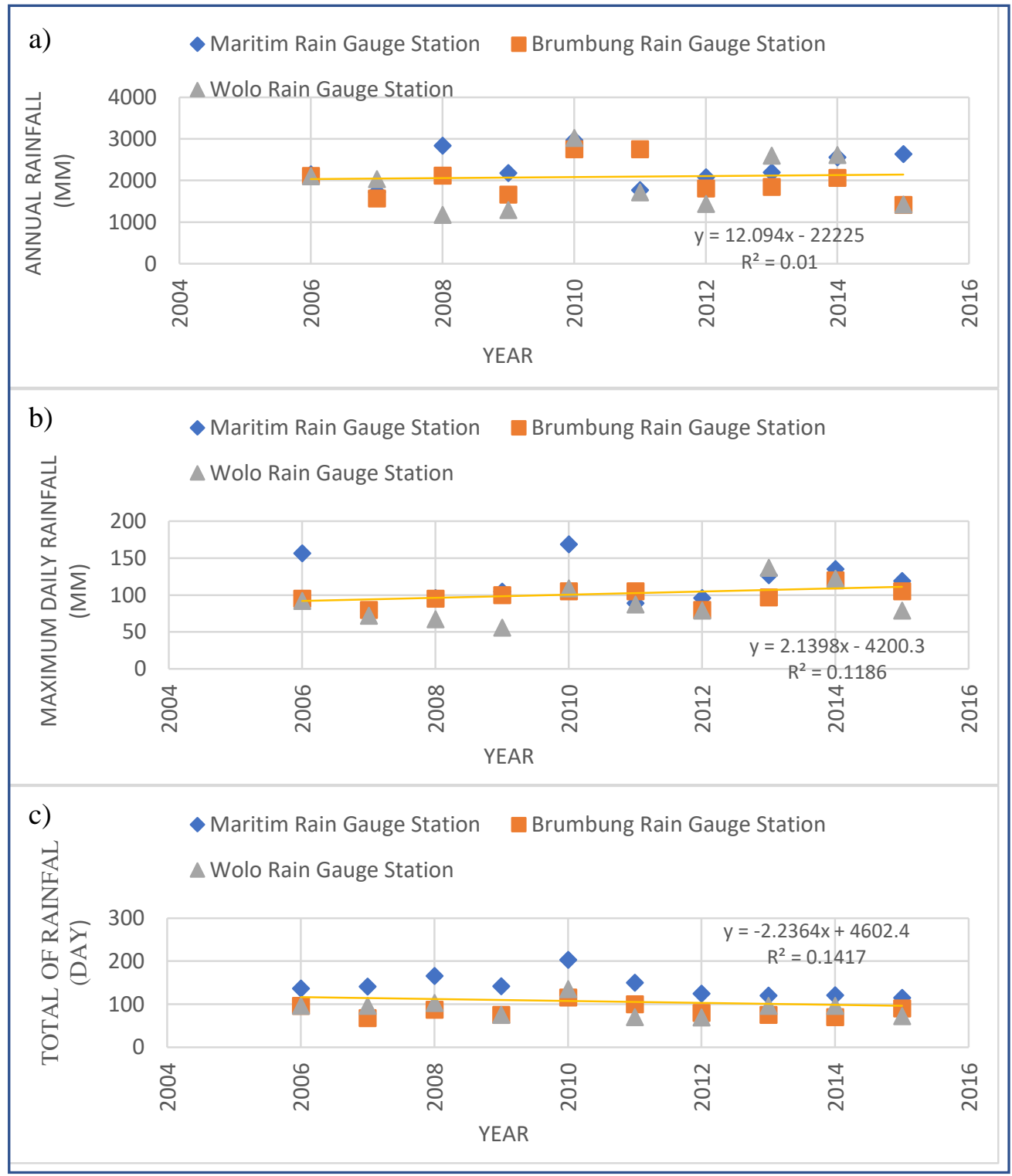

Fig. 2. Rainfall Characterisation Each Rain Gauge Station

\subsection{Design Flood}

\subsubsection{Rainfall Intensity}

The simulation of rainfall intensity was demonstrated by the IDF curve (Intensity Duration Frequency) showed in (Fig 3). The empirical formulas are used to construct the rainfall IDF curve. The curve in the figure was evaluated using the daily rainfall, for different return periods $\mathrm{T}$. In particular, the obtained IDF curve underestimates values less than four 
hours while overestimates values greater than four hours, in contrast with the curve developed by Soro et al. (2010) which obtained IDF curve showed underestimates values less than one hour while overestimates values greater than one hour. Although overall the curve is dissimilar to that developed by Soro et al (2010), it probably caused by the probability parameter used in the analysis. They used Log normal, GEV and Gumbel distribution fitted by maximum likelihood. While this research used a Log Pearson III distribution approach, we were considering a poor data contained, using this kind of distribution it may be preferable to fit with a distribution that requires an estimate of the skew coefficient, such as a logPearson Type III distribution. The data can be plotted to determine the adequacy of the curve. Since 1967, the U.S Water Resource Council has recommended and required the use of LP3 distributions for all U.S analysis (Millington et al., 2011). At the same time LP 3 was recognise as a recommended basic distribution for defining the annual flood series (Xiao et al., 2009).

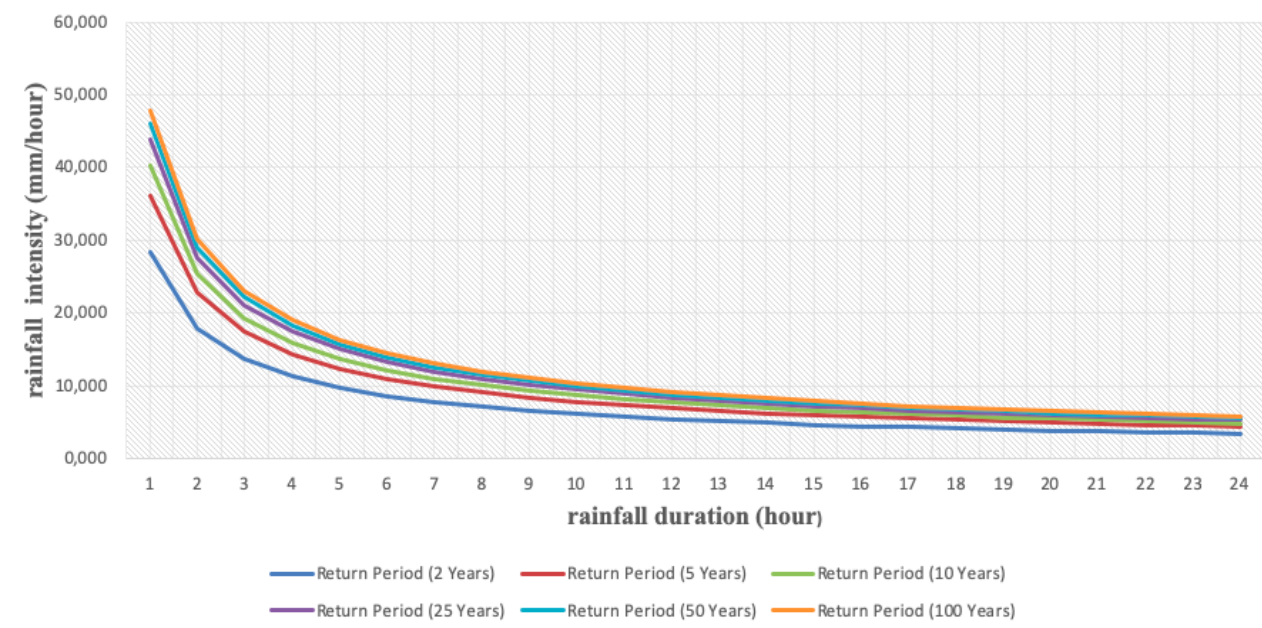

Fig 3. Intensity Duration Frequency Curve

Intensity corresponds with the duration and frequency can be expressed by the curve Intensity-Duration-Frequency (IDF). IDF curves can be used to calculate flood plan. The maximum rainfall using an algebraic average of 10 years of observations derived from the 3 rain gauge stations, namely Maritim, Brumbung and Wolo. Then looking for the patterns of rainfall distribution through normal distribution and statistical parameters logarithmic and analysed the design of rainfall by Log Pearson III method. The intensity of rainfall calculates by using the rational method. The analysis calculated using the method of flood discharge plan to use rational methods to obtain flood peak discharge flow in the area research areas prone to the flooding. Then result calculation of drainage capacity in the research area showed by the intensity return period of rainfall for 2,5,10, 25, 50, 100 years were 81.656 $\mathrm{mm} /$ hour, $104.262 \mathrm{~mm} /$ hour, $116.00 \mathrm{~mm} /$ hour, $126.511 \mathrm{~mm} /$ hour, $132.773 \mathrm{~mm} /$ hour, $138.030 \mathrm{~mm} /$ hour.

\subsubsection{Flood hydrograph analysis}

The design of flood hydrograph has been analysed through rainfall analysis from 2006 until 2015 where then we calculated the flood discharge. It was associated with the downstream discharge station. The result found the flood discharge will increase in line with 
the characteristics of rainfall, where the peak of maximum daily rainfall tends to increase $2.139 \mathrm{~mm}$ per year. The time to peak and the total duration of the hydrograph scenarios have been scaled compared to recorded flood waves (time to peak and the total duration may be up to 2 times shorter in some cases). The flood scenario from prolonged rainfall occurred in Tenggang river showed in (Fig. 4). Based on the result, it is defined the flood peak reached close to 10 hours after the beginner of flood wave where the total of flood duration equals to 25 hours. The shape of the hydrographs reflects the shape of flood waves occurring in the Tenggang river with a rising limb being steeper than the falling limb.

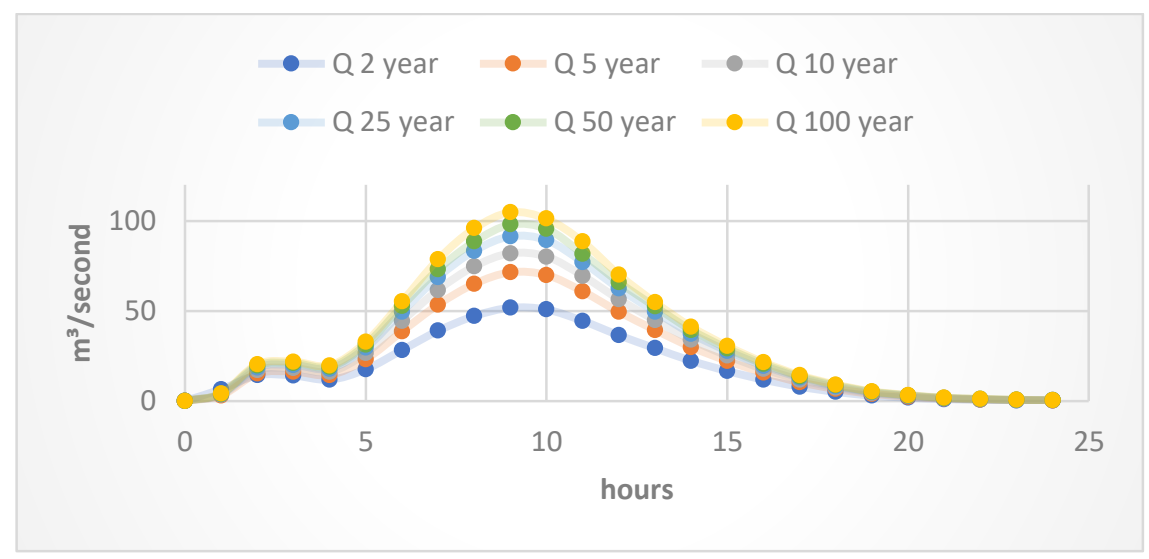

Fig 4. Flood Hydrograph of Tenggang River

Some suggestions from the research are the analysing of the effect of climate change on rainfall required longer historical data. It needs more than 10 years, so accurate results would be achieved. Next, the number of rain gauge stations especially in the Tenggang river is actually adequate however the availability of data (continuity, quality, and completeness) was still insufficient. It is necessary to rationalize the climatology station. Finally, the lack of data on flood hydrograph results in the difficulty of validating research results. Therefore, it is recommended to install and or operate an Automatic Water Level Recorder (AWLR) station in each river. To elaborate on some methods for future climate change it needs the analysis of propagation of the flood and simulated some of the deposit influence the river with the typical channel as well as showed by Virginia et al., (2014). At the same time, we need the analysis of future IDF through climate change such if the temperature increases 2 degrees, it needs to change the IDF pattern. Hence, the future rainfall run-off analysis is also needed numerical analysis (Li et al., 2009, Virginia et al., 2014) and or experimental data analysis such as ANFIS (Suparta, 2011). It is worthwhile as a synthetic method of flood estimation that can be presented the flood forecasting. Otherwise, multicharacteristic synthesis index (MSI) proposed by Xiao et al., (2009) was might be another suitable method for a new way for derivation and reassessment of the design flood hydrograph. 


\section{CONCLUSIONS}

The research conclusion revealed the annual rainfall and maximum daily rainfall tends to increase, whereas the number of rainy days tends to decrease. Annual rain height increased by an average of $12.094 \mathrm{~mm}$ per year, while the maximum daily rainfall increased by an average of $2.139 \mathrm{~mm}$ per year, and the number of rainy days decreased by an average of 2 days per year. Subsequently, the IDF produced based on historical data where the maximum daily rainfall was increased by an average of $2 \mathrm{~mm}$ per year. Flood discharge with high return times quantitatively increased compared with lower return times. On the contrary, in percentage, the flood discharge with a low return period has higher compared to the flood discharge with a high return period. Flood discharge measurements constitute the most important data for improving the rating curves and for addressing the hydrological issue. Furthermore, it needs more than 10 years data to confirm the accurate climate change effect in Tenggang river.

\section{R E F E R E N C E S}

Califano, F., Mobilia, M. \& Longobardi, A. (2015) Heavy Rainfall Temporal Characterization in The Peri-Urban Solofrana River Basin, Southern Italy. Procedia Engineering, 119, 1129 - 1138

Costache, R. (2014) Using GIS techniques for assessing lag time and concentration time in small river basin. Case study: Pecineaga River Basin, Romania. Geographia Technica, 9(1), 31- 38.

De Paola, F., Giugni, M., Topa, M.E. \& Bucchignani, E. (2014) Intensity-Duration-Frequency (IDF) rainfall curves, for data series and climate projection in African cities, Springer Plus, 3,133

Diaz, J., Holscher, D., Leuschner, C \& Hendrayanto. (2006) Rainfall partitioning in relation to forest structure in differently managed montane forest stands in Central Sulawesi, Indonesia. Forest Ecology and Management, 237, 170-178

Emanuel, K. (2005) Increasing Destructiveness of Tropical Cyclones Over the Past 30 Years. Nature, 436, 686-688

Fu, B., Wang, J., Chen, L \& Qiu, Y. (2003) The effects of land use on soil moisture variation in the Danangou catchment of the Loess Plateau, China. Catena, 54, 197-213.

Gyori, M. M. \& Haidu, I. (2011) Unit hydrograph generation for ungauged sub watersheds. Case study: the monorostia river, arad county, Romania. Geographia Technica, 6(2), 23 - 29

Haidu, I., Batelaan, O., Crăciun, A.I., \& Domnița, M. (2017) GIS module for the estimation of the hillslope torrential peak flow. Environmental Engineering and Management Journal, 16(5), 1137-1144.

Li, L., Hong, Y., Wang, J., Adler, R. F., Policelli, F. S., Habib, S., Irwn, D., Korne, T. \& Okello, L. (2009). Evaluation of the real-time TRMM-based multi-satellite precipitation analysis for an operational flood prediction system in Nzoia Basin, Lake Victoria. Africa Nat Hazards 50,109123.

Martin, E. A., Buchberger, S.G., Chakraborty, D. (2015) Reliability of harvested rainfall as an auxiliary source of non-potable water. College Procedia Engineering 13th Computer Control for Water Industry Conference, 119, $1119-1128$.

Mello C.R., Viola MR., Beskow S, Norton LD. (2013) Multivariate models for annual rainfall erosivity in Brazil. Geoderma, 202-203, 88-102.

Millington, N., Das, M. \& Simonovic, S. P. (2011) The Comparison of GEV, Log-Pearson Type 3 and Gumbel Distributions in the Upper Thames River Watershed under Global Climate Models . Water Resources Research Report, Department of Civil and Environmental Engineering The University of Western Ontario London, Ontario, Canada.

Murdiyarso D. (2003) Protokol Kyoto: Implikasinya bagi Negara Berkembang, Penerbit Buku Kompas, Jakarta.

O'Gorman, P.A. (2015) Precipitation Extremes Under Climate Change, Current Climate Change Reports, 1, 49-59. 
Pintubatu, D.C., Sudarsono, B. \& Wijaya, A.P. (2013) Analisis Pengarus Perubahan Lahan Terhadap Kerawanan Banjir di Daerah Aliran Sungai Tenggang Kota Semarang. Jurnal of Geodesi Undip, 2(4), $240-252$.

Pravalie, R. (2014) Analysis of Temperature, Precipitation and potential evapotranspiration trends in Southern Oltenia in the context of climate change. Geographia Technica, 9(2), $68-84$.

Shrestha, D.P. \& Zinck, J.A. (2001) Land use classification in mountainous areas: integration of image processing, digital elevation data and field knowledge (application to Nepal). Int. J. Appl. Earth Obs. Geoinformation, 3, 78-85.

Soro G.E., Goula Bi, T.A., Kouassi F.W. \& Srohourou B (2010) Update of Intensity-DurationFrequency Curves for Precipitation of Short Duration in Tropical Area of West Africa (Cote D'ivoire). Journall of Applied Sciences 10(9), 704-715.

Suparta, W, (2011) Using ANFIS Times Series Technique to Predict Rainfall in South Tangerang, Indonesia. Bulletin of Electrical Engineering and Informatics, Vol.x, No.x, Month 2011, pp. $4 \mathrm{xx} \sim 4 \mathrm{xx}$.

Suparta, W \& Yatim, A.N.M. (2019) Characterization of heat waves: a case study for peninsular Malaysia. Geographia Technica, 14(1), 146 - 155.

Suripin, S. \& Hilmi, M. (2015) The loss of Semarang Coastal Area due to Climate Change and Land Subsidence, International Conference on Techniques, Development and Management of Delta Area, February 20, 2015, Semarang.

USACE., (2010) Hydrologic Engineering Canter's River Analyses System User's Manual, U.S. Army, Washington, DC.

Villanueva, V.R., Wyzga, B., Mikus, P., Hajdukiewicz, H., \& Stoffel., M. (2016) The role of flood hydrograph in the remobilization of large wood in a wide mountain river. Journal of Hydrology, 2, 60-74.

WWF (2012) Climate Change in Indonesia: Implications for Humans and Nature, http://wwf.panda.org/about_our_earth/aboutcc/problems/rising_temperatures/hotspot_map/indone sia. cfmBrown, L.C. dan Barnwell, T.O., 1987. The Enhanced Stream Water Quality Models QUAL2E and QUAL2EUNCAS: Documentation and User manual, US EPA, Georgia.

Xiao, Yi., Guo, S., Liu, P., Yan, B. \& Chen, L. (2009) Design Flood Hydrograph based on Multicharactheristic synthesis Index Method. Journal of Hydrologic Engineering, 14(12), 1-7.

Yavuz, H \& Erdogan, H. (2012) Spatial Analysis of Monthly and Annual Precipitation Trends in Turkey. Water Resource Manage, 26, 609-621. 